Journal of Management and Economic Studies

2019, 1(8): 11-21 DOI: 10.26677/TR1010.2019.286 Journal Homepage: https://www.jomaes.org

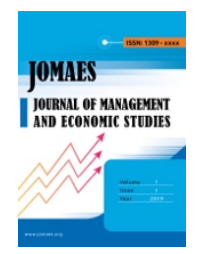

\title{
Environmental Protection: An Evaluation of the Activities of the Oyo State Environmental Protection Agency
}

\author{
Ogedengbe Peter Shakede \\ Department of Estate Management, University of Benin, Benin City, Nigeria. \\ psogedengbe@yahoo.com
}

\author{
Alohan, O. Ernest \\ Department of Estate Management, University of Benin, Benin City, Nigeria. \\ Corresponding author: ernnygentle2009@gmail.com
}

\begin{abstract}
In a bid to conquer the environment for his survival, man has over the years been attacking it through exploration and exploitation. This rate has continued to rise with advancement in technology that is pivotal to industrialization. Due to the pressures of population and technology, the biophysical environment is being degraded, sometimes permanently. The paper appraises the Oyo State Environmental Protection Agency as the body charged with the responsibility of protecting the environment with a view to determining the environmental situation of the state. Questionnaires were administered on some residents of Ibadan South-West local government area, which was divided into high, medium and low-density areas to elicit information on the environment and the activities of the state environmental protection body. In addition, some officials of this body were interviewed. The data collected were analyzed and presented using simple statistical methods. The results showed that the Agency faces a plethora of problems emanating from poor funding with its attendant inefficient implementation of programs. The paper recommended among others that public enlightenment should be given topmost priority.
\end{abstract}

Keywords: Environmental protection, awareness and Environmental degraded

\subsection{Introduction and Problem}

Population increase has over the years prompted man to technologically manipulate the environment in order to meet his needs. This process that adversely affect the environment in developing countries, as noted by Mabogunje (1993), assumes different dimensions ranging from production problem and under consumption, to traffic problem and poor housing, water supply, air and water pollution, urban wastes disposal and health services, etc.

As many Nigerian cities pass the one million mark in population, collection and disposal of wastes have become a major urban environmental problem (Egunjobi 1986). In Lagos, Ibadan, Kano, Port Harcourt and Enugu, uncollected heaps of solid wastes, which constitute health hazards, are observable. In addition, the disposal sites of most of the cities have also become environmental hazards, the wastes are not treated sanitarily while in some cases, and the disposal sites have been engulfed by residential and other urban land uses (Egunjobi 1999). In Nigeria, 
haphazard development, rapid urbanization and industrialization, uncontrollable population growth rate, deforestation, poverty, soil erosion, poor municipal solid wastes management, inadequate supply of portable water, lack of basic sanitation and negative socio-cultural values are few examples of human activities and conditions that degrade the environment and which pose a threat to human health. The rapid increase in industrial, agricultural and other economic activities has further compounded the deplorable state of the physical environment in the Nigerian urban centers.

The public outcry over the illegal dumping of toxic and hazardous wastes in Koko village in defunct Bendel state led to the establishment of the Federal Environmental Protection Agency (FEPA) in 1988 as a national body to give regulatory guidelines on the protection of the environment against pollution and all the other human activities that have negative impacts on the environment. In spite of the establishment of FEPA, the menace of environmental degradation resulting from pollution and other human activities are still evident in most Nigerian cities. There is still no sustained and organized system for the collection and disposal of solid wastes, which are continually being, generated in houses, markets and other activity zones.

In each of the 36 states of the federation, state Environmental protection Agency was established in compliance with the provisions of FEPA Decree to monitor the state of the physical environment in each state. This led to the establishment of the Oyo State Environmental Protection Agency in 1999.

In large part of Ibadan, water is not always available to flush water closet toilets; pit latrines are dug without environmental considerations near water wells for domestic use, which make typhoid fever to be prevalent. The outbreak of cholera epidemic in the city between 1971 and 1973 mostly affected the traditional core areas with high density where water and sanitary facilities were almost inadequate. (Adesina 1987).

The Oyo state Environmental protection Agency was established to formulate and enforce environmental policies, which include regulations on wastes collection and disposal, general environmental control and protection, control and regulation of the ecological system and all related activities. As part of its responsibilities, the Oyo State Environmental Protection Agency is charged with the responsibility of monitoring and controlling all forms of environmental degradation from Agricultural, Industrial and governmental operations and conduct public enlightenment campaign in order to disseminate vital information on environmental and ecological matters amongst others. The paper tries to examine the environmental status of the state taking into consideration the role of the Oyo State Environmental Protection Agency, in the protection of the environment

\subsection{Literature Review}

Environment, which in the Italian language is referred to as "ambiente" in its simplest term means the ecosystem. Man's interaction with the ecosystem and its consequences on the environment has over the years been a concern all over the world. In Nigeria, several environmental problems amongst which include, desertification, soil erosion, oil pollution, deforestation, global warming, soil erosion, improper pesticides amongst others have been identified (Ijaiya and Joseph, 2014). Celikyay and, Uzun (2007) opined that environmental problems has been associated with industrialization, increased population, irregular urbanization and the use of natural resources. Man and its environment are inseparable and 
would continue to engage in one economic and ecological activity for his survival and sustenance. Hence the need for sustainable environmental protection.

Environmental protection was defined by business dictionary as "those policies and procedures aimed at conserving the natural resources, preserving the current state of the natural environment and, where possible, reversing its degradation". These policies are meant to provide guidance on the way our natural resources are used and conserved, preserved and the control or total prevention of the degradation of the environment due to human actions. The act of the protection of the environment is carried out by the individuals, organisations or institutions and the government. Celikyay and, Uzun (2007) viewed environmental protect as a process which consist of four major component which are environmental law, environmentally sensitive planning, environmentally sensitive governance and environment consciousness. They opined that no environment can be protected without at least one of these component which facilitate the process of environmental protection.

In 1988, the Federal government created the Federal Environmental Protection Agency (FEPA) as a way of responding to the environmental problems and the national public outcry occasioned by the illegal dumping of toxic waste in Koko, South west Nigeria (Nabegu, Mustapha and Naibbi, 2017; Ogbodo, 2009). The State Environmental Protection Agencies (SEPA) were later set up and were complemented by the Local Governments Environmental Protection Agencies (Ijaiya and Joseph, 2014). The Federal Environmental Protection Agency (FEPA) were the sole initiators of policies on environmental protection, advise the Federal Government on environmental issues and enforcement on compliance to environmental standards, regulations, policies and guidelines. The State Environmental Protection Agency advises the State Government on environmental management policies, public enlightenment and educate, monitor and control the disposal of all forms of waste, monitor and control all forms of environmental degradation amongst others.

With these agencies in place, there is still dissatisfaction of the state of the extent of environmental protection in the country. Nabegu et al, (2017) lament the poor state of enforcement of the existing regulations in the country, resulting in both social and environmental welfare losses. They attribute this to lack of national data, lack of technical capacity of staff responsible for the enforcement of environmental regulations, inadequate institutional framework and weakness of the institutions in charge of environmental regulations leading to corruption among others.

\subsection{Environmental Planning and Management (EPM)}

Taiwo and Busari, (1997) simply viewed the EMP process as "the basic steps needed to carry out environmental management plans i.e. the overall process through which a city's environment is or can be managed". Lekwot, Balasom, Dyaji and Yakubu (2014) viewed EPM process as a strategy for solving the many environmental problems affecting man's ecosystem in our contemporary world. It is an articulated, analytical framework, and logical structure, which facilitates better understanding of the dynamism of urban development and environmental issues and helps in evolving convincing guidelines for intervention. It emphasizes the close interrelationship between urban development and urban environment, and stresses the crucial roles of economic, political and social processes.

The process is made up of both descriptive (analytical) and normative (prescriptive) mechanism for modern environmental management. The combination of the two mechanisms in the EPM 
process allows for a constant flow of information from analysis to practice (that is, from policy) project formulation (to implementation) and vice-versa.

The Environmental Planning and Management (EPM) process was designed by United Nations Center for Human Settlement (UNCHS-Habitat) to facilitate effective urban environmental management of cities. In fact, the process is the technical basis of the global Sustainable Cities Programs (SCP) of the United Nations organ and its practicability is being demonstrated already in the sustainable Ibadan project.

Taiwo and Busari, (1997) highlighted the basic elements of the EPM process as follows:

$>$ Clarifying environmental issues.

$>$ Involving those whose co-operation is required,

$>$ Setting priorities

$>$ Negotiating issues-specific environmental management action plan

$>$ Formulating urban wide environmental management strategies.

$>$ Initiating high priority projects and programs.

$>$ Monitoring and evaluating programs and making periodic adjustment and

$>$ Strengthening environmental planning and management capabilities;

For the enhancement of its application, the above are merged into four major steps:

1. Identification of urban environmental issues and involvement of stakeholders.

2. Formulating urban environmental management strategies.

3. Formulating and implementing environmental action plans.

4. Institutionalizing Environmental Planning and Management (E.P.M)

\subsection{The Strength of EPM Process}

1. The EPM process emphasizes and encourages bottom-up planning approach, which enhances public participation and building commitment of all stakeholders and actors in the city.

2. The EPM process deliberately combines planning with action against the traditional planning practices where the two activities are separated, the experience is that actions are integral parts of the process of evolving strategies and action plans to deal with environmental issues.

3. The EPM process has built-in mechanism for strengthening local capacity, plan and management of the environment effectively; also it has the capacity to alternative environmental problems so that full potential of urban areas will be accomplished.

4. The EPM process provides a systematic approach for a better planning and effective management of the dynamism of urban development (Taiwo and Busari 1997).

\subsection{Citizens' Participation}

The United Nations Rio Conference on the Environment and Development (1990) emphasized the concept of sustainable development -that is development that meets needs of the present without compromising the ability of future generation to meet their own needs. The conference emphasized that environmental issues are best handled with the participation of all concerned citizen at relevant levels.

Citizen's participation is the act of allowing individual citizens or group of citizens within a community to take part in the formulation and proposals on issues that affect the whole community (Oladoja 1988). In this approach, every citizen in the community is believed to have unrestricted access to necessary and relevant information and is free to express opinion on issues 
at stake. Onibokun et al (1995) noted that citizen participation in UK, US and other developed nations are aided by the following factors:

a. The absence of nagging or persistent problems such as poverty, social insecurity, environmental degradation etc.

b. The Equilibrating attraction of collective group action, supported by both social theory and experience.

c. The emergence of advocacy planning; and

d. The claiming of the democratic fundamental human rights of citizens by citizens leading to their empowerment.

However, in the developing countries, by far the most common factors of citizens' participation include the provision of services by individuals, groups and the community at large. It is such participation that gives the people the pride of ownership.

The principle of citizens' participation emphasizes the initiative of the people as a way of stimulating the active involvement of all the citizens; it implies that success is assured where effort of the local people is supplemented by the direction of government authorities. Citizens' participation is sine-qua-non-for accelerating social changes in areas such as community development and family planning among others. Citizens' participation tends to:

1. Increase the degree of "we" feeling or cohesiveness that people have with their society or country.

2. Provide the participants with overall state or country point of view instead of the traditionally parochial, ethnic, tribal, and local government point of view.

3. Decrease the amount of conflict, hostility and stiff competition among participants.

4. Develop a work climate as a result of other tendencies in which the fellow citizens have opportunity to be more creative and develop suitable ideas beneficial to the entire country among others.

These two theoretical concepts (EPM process and citizens' participation) are very relevant for the enhancement of the activities of Oyo State Environmental Protection Agency. Also it gives all the stakeholders, especially on environmental issues, the opportunity to be adequately informed and properly involved.

\subsection{Conceptual Issues}

Various authors and schools of thought have noted with dismay the deteriorating physical environment and recommended the need to increase public awareness and participation in order to redress the ugly trend. Abiodun (1998), argues that one of the most urgent problems confronting African cities today is how best to plan and manage the environment. Globally, an environment free of health hazards is generally being canvassed. The commonest type of environmental problems as found in literature is in the area of deforestation, desertification, pollution, drought, environmental sanitation, lack of environmental education, absence of orderly land use pattern, difficulties in enforcing development control legislation and regulations and general absence of an effective urban management system.

Ayoade (1992), (CASSAD (1991), Onibokun and Faniran (1995) noted that, with regards to urban centers, the environment is plagued by several forms of environmental pollution including air, water and land pollution. Oluwu and Akinola (1995), noted that Nigerian cities epitomize the urban environmental crisis -an account of continued migration of people to the cities, the 
increasing demand for urban services and ineptitude city managers to plan and implement appropriate land use strategies.

Nwankwo and Ifeadi (1988) carried out a careful review of the scope of current crude oil operation in Nigeria, and identified sources, causes and effects of emission of pollutants into the environment at the various phases of production, refining and marketing of petroleum products in the country. They recommended that environmental quality considerations should constitute the essential criteria of any policy formulation in the oil industry, the institutional arrangement for pollution management must of necessity, involve at least the community leaders in environmental education awareness and monitoring. No measure aimed at combating environmental problems can be effective and efficient without carrying people along.

Chokor (1998) views environmental awareness as a synthesis of peoples' perception and interpretation of environmental issues. He also argued that the first step in the effective control and management of the environment is the development of the public environmental awareness. So, people must be aware of the possible consequences of their actions with respect to their interaction with the environment. Adeniji (1991), Olurin (1999), Chokor (1998), Wahab (1998), and Oluwafemi, Odita (1997) and Solomon (2010) see environmental awareness as a vital tool for the successful implementation of environmental policy.

UNCHS (1997) deduced that one of the key lessons learnt from the environmental planning and management city consultation for Ibadan held in 1995 was that the previous inclusion of many stakeholders in the identification, development and implementation of urban development options has contributed to the lack of lasting solutions to Ibadan environmental problems. In madra/ Chennara in India, Exnora and NGO used EPM process to identify key environmental problems and the lesson learnt after successful completion of the exercise include; participation and good human authorities and community participation, resulted not only in better solid waste management but also willingness to try concept such as waste separation at source. Among the priorities for the people of Katowice in Poland was to improve public participation in the city to have access to information on new technologies and to find out about public empowerment and financing techniques that could be applied to reduce environmental degradation. The Accra Metropolitan Authority in waste management department can cater for only 60 percent of the daily 1,200 tonnes of garbage generated (Urban Edge, 1991). It further added that the greater problem is lack of cultural awareness of the need for proper sanitation "we need to admit that there is lack of education with regards to proper disposal of waste that makes the problems worse and that a structural system that enforces correct behaviour is needed".

Also most cities have found that successful environmental planning and management requires understanding, agreement, and coordinated action by the full range of public, private and popular sector groups and organizations (stakeholders at neighborhood, community, city and national levels (UNCHS/UNEP). Urban Edge emphasized that, among the constraints in environmental problems management in Sao Paulo, Brazil are: limited enforcement capacity, a complex set of environmental laws, reliance on limited choice on management tools, lack of cost recovery, insufficient co-ordination across levels of government and inadequate public participation.

In a proposed strategy for action in Jakarta and Indonesia, the participants noted that "the fight against pollution is a total fight: it needs simultaneous involvement at all levels: the household level, the neighborhood level, and city, and region, national and global levels". In Toronto and 
Canada, there is a general consensus that communities and residents must be allowed to have more influence on environmental decision-making. As they rightly observed "communities must have more influence in decision makings and they must be made to feel responsible for the physical environment" (Urban Edge 1991).

It is assumed that if people are aware and well informed about the consequences of their actions and activities on the physical environment through public awareness and participation, such could bring about a positive change and prevent future disasters that could emanate as a result of environmental degradation.

\subsection{Methodology and Analysis}

The study area was divided into three areas according to densities and residents were selected from each density area for examination using stratified random sampling technique in order to know the state of the environment. In addition, officials of the Oyo State Environmental Protection Agency charged with the responsibility of protecting the environment were interviewed in order to know about their activities in the state. A total of 120 questionnaires that were administered on the residents of Ibadan South West local government area and the interviews conducted with some officials of the Oyo State Environmental Protection Agency form the basis of analysis shown below:

\subsection{Appraisal of SEPA's Activities}

One of the statutory functions of SEPA is primarily to conduct public campaign and disseminate vital information about the environment to the people. However, findings from the survey conducted revealed that the level of awareness about Oyo State Environmental Protection agency is very low. This is shown in the table below:

Table 1: Level of awareness of SEPA activities

\begin{tabular}{|l|l|l|}
\hline Response & No of respondents & Percentage (\%) \\
\hline Yes & 49 & 40.8 \\
\hline No & 71 & 59.2 \\
\hline Total & 120 & 100 \\
\hline
\end{tabular}

Source: Author's field survey.

Table 1 shows that $40.8 \%$ of the total respondents claimed they know about SEPA and its functions, while the remaining 59.2\% claimed ignorance of SEPA and its activities depicting low level of awareness, hence can be inferred that the agency is fairly effective.

Table 2: Impact of SEPA activities on the Localities

\begin{tabular}{|l|l|l|}
\hline Response & No of respondents & Percentage (\%) \\
\hline Yes & 51 & 42.5 \\
\hline No & 69 & 57.5 \\
\hline Total & 120 & 100 \\
\hline
\end{tabular}

Source: Author's field survey.

The findings on how much impact of SEPA have been felt in the localities revealed that $42.5 \%$ of the respondents claimed that much impact has been felt while $57.5 \%$ said they have not felt its impact in any way, meaning that SEPA's impact is really not being felt in the area. 
Table 3: Awareness of Environmental Campaign and Enlightenment

\begin{tabular}{|l|l|l|}
\hline Response & No of respondents & Percentage (\%) \\
\hline Yes & 25 & 20.8 \\
\hline No & 79 & 79.2 \\
\hline Total & 120 & 100 \\
\hline
\end{tabular}

Source: Author's field survey.

The outcome of the question as to whether SEPA has undertaken any environmental awareness or enlightenment programme which the agency is mandated according to the Edict to do, a small proportion of $20.8 \%$ responded in the affirmative while a larger proportion of $79.2 \%$ responded otherwise which clearly reveals that SEPA is not really doing well in this aspect of creating and conducting public awareness and campaign for the people.

Table 4: Showing Usage of Toilet Facilities

\begin{tabular}{|l|l|l|}
\hline & No of respondents & Percentage (\%) \\
\hline Water closet & 30 & 25 \\
\hline Pit latrine & 75 & 62.5 \\
\hline Bush system & 15 & 12.5 \\
\hline Total & 120 & 100 \\
\hline
\end{tabular}

Source: Author's field survey.

It is a common sight especially in areas like Foko, Agbeni and other core parts of Ibadan South West Local Government Area, to see human waste being dumped in drains. Table 4 above also supports this.

\subsection{Findings and Conclusion}

\subsection{Assessment of Oyo State Environmental Protection Agency}

In assessing SEPA's activities, one can see clearly that the environment has not felt the impact of the efforts of SEPA in trying to create a conductive physical environment that is free of pollution and degradation.

\subsection{Waste Management}

One prominent problem noticed during the survey was the menace of wastes within the study area; wastes are indiscriminately dumped into drainage channels. This constitutes very serious health and ecological hazard not only to the inhabitants of the area but the entire physical environment. The stench emanating from this area is very offensive and injurious to human health. However, serious business transaction is going on unabated in this area and the people seem not to see anything wrong in the deplorable and filthy environment probably due to lack of awareness about environmental pollution and its attendant health hazards.

\subsection{Illegal Conversion}

Virtually all-available space irrespective of location and suitability is now being used for commercial purposes. The space under the overhead bridge at Molete is now a commercial area where buying and selling operate.

\subsection{Street Hawking}

Another major problem is the menace of street hawking which usually impedes the flow of vehicular traffic. In fact, it is a usual phenomenon to find hawkers displaying their wares along 
the road and hindering the flow of traffic. Also important is the exposure of the under-aged engaged in street hawking to all forms of environmental hazards.

\subsection{Problems Confronting SEPA}

Oyo State Environmental Protection Agency is currently facing diverse problems inhibiting it from properly and efficiently caring out its obligations and functions part of which is adequately informing and enlightening the public as well as dissemination of vital information to the public. Some of the problems are discussed below:

\subsection{Poor Funding}

The economic recession being experienced in Nigeria has a toll on many agencies and governmental departments including Oyo State Environmental Protection Agency. What obtains is poor funding from the state government and this impedes the activities of SEPA in the discharge of its duties.

\subsection{Lack of Transportation Facilities}

For the whole agency, only two station wagon cars are available to transport officials on duty. This is a serious problem considering the size of the study area.

\subsection{Inadequacy of Qualified Manpower.}

Environmental management and protection is a highly technical field that requires skill and expertise. Generally in Nigeria and Oyo state in particular, environmental experts are very few compared with the enormity of environmental problems confronting our cities. This findings is in tandem with the position of Nabegu et al, (2017) when they attributed one of the reasons for the poor enforcement of existing environmental laws and regulations to lack of technical capacity of staff.

\subsection{Lack of Accommodation}

There are not enough accommodation facilities to enable the officers and personnel to be adequately housed and made comfortable to discharge their duties. We have overcrowding in offices and this does not provide a conductive environment to work.

\subsection{Haphazard Development}

The survey conducted shows that haphazard development adorns the whole study area. Here it was discovered that developers fail to comply with laid down rules and regulations and grossly defeating the objectives of creating an aesthetically pleasing and functionally related physical environment that is conducive for living, working, recreating and circulating.

\subsection{Conclusion and Recommendation}

In assessing SEPA, it becomes clear with the catalogue of problems plaguing the physical environment and the level of ignorance expressed by the public, there is communication gap between the public and SEPA. It is recommended that the state government should provide more funding to the agency, adequate and comfortable office accommodation for the staff, more vehicles for adequate monitoring and enforcement of environmental protection laws and employ more qualified personnel with the required skill to handle the technical aspect. They should also embark on awareness programme to educate the public of the need for environmental protection and their roles to facilitate high level compliance to environmental protection law. Illegal conversion of open space for commercial use and street hawking should be addressed by all the relevant environmental protection agencies. 


\section{References}

Adeniji, J.D (1991). "The role of Environmental Education Training and Public Awareness" in Aina, E.O and Adedipe, N.O (eds): The Making of the Nigerian Environmental Policy. Onibonje publishers. Ibadan.

Adesina H.O. (1987). "The temporal and Spatial Analysis of cholera Diffusion within Ibadan, Nigeria", 1971-1974: in Akhatarled" Health and Disease in Tropical Africa: London, Paris, New York: Hardwood Academic Publishers.

Agboola, (1998).A review of Environmental Component in Nigeria's Development Plans, 19401986 "in Sada, P.O and Odemerho, F.O. proceeding of Seminar on Environmental issues and Management in Nigeria Benin City.

Ajibade, L.T. (2000). “Techniques of creating Environmental Awareness in Nigeria, in Jimoh, H.I and Ifabiyi, I.P. (eds) in Contemporary issues in Environmental studies Haytee press and publishing company Ltd. Ilorin, Kwara State, Nigeria.

Abiodun, J.O. (1998). “Environment, Poverty and Sustainable Development in Nigeria Cities” The Nigeria Social Scientist Journal

Ayoade, J.O (1992). Focus on the Urban Environmental Ecology in Onibokun, A.J (eds). Paper on urban Research Agenda for 1990's in English speaking West Africa Sub-Region Ibadan. CASSAD.

Cassad, (1991). Centre for African settlement studies and Development: Impact of Structural Adjustment Programme (SAP) on investment in Housing and Environmental Development: Final Report Ibadan (Cassad).

Celikyay, S. and Uzun, N., (2007). Major Components of Environmental Protection Process. Retrieved from https://www.researchgate.net/publication/237804883

Chokor, B.A. (1998). "Environmental Awareness and Effective Environmental Pollution control" in Sada, P.O and Odemerho, F.O. (eds) Environmental issues and Management in Nigeria Development. Evans Brothers (Nigeria Publishers) limited, Ibadan Nigeria.

Cheema, G.S (1998). Innovative Urban Management Practices: Urban Edge Journal 3(4).

Egunjobi T.O. (1986a). "Problems of Solid waste management" In Nigeria Urban centers in Adeniji, E.O and Bello-Imaam I.B (eds). Development and the Environment, NISER, Publishers Ibadan.

Egunjobi, Layi (1986 b) “Urban Environmental Noise Pollution” In Nigeria: Habitat international Journal, 10 (4).

Egunjobi (1999) “Our Gasping Cities" An Inaugural Lecture of 1999 at University of Ibadan, Faculty of social science, Ibadan.

Business $\quad$ Dictionary. Retrieve from http://www.businessdictionary.com/definition/environmental-protection.html 
Ijaiya, H., and Joseph, O. T. (2014). Rethinking Environmental Law Enforcement in Nigeria. Beijing Law Review, 5, 306-321. http://dx.doi.org/10.4236/blr.2014.54029

Lekwot, E.V., Balasom, K. M., Dyaji, L., and Yakubu, A. A., (2014). Environmental planning and management (EPM) as a strategry for solving environmental problems in Niger delta region: A study of Bonny Island, Rivers State, Nigeria. International Journal of Innovation and Applied Studies Vol. 9(1) pp. 239-248. http://www.ijias.issr-journals.org/

Mabogunje, A.L. (1993) Infrastructure: The crux of Modern Urban Development. Urban Edge Journal 1 (3).

Nabegu, Mustapha A. and Naibbi A., (2017). Environmental Regulations in Nigeria: A Mini Review. International Journal of Environmental Sciences \& Natural Resources. 1(5): 02555573. DOI: 10.19080/IJESNR.2017.01.555573

Nwankwo, N and Ifeadi, C.N. (1988). "Case studies of Environmental Impact of oil production and marketing. In Sada, P.O and Odemerho, F.O (eds) in Environmental issues and management in Nigeria Development. Evans. Brothers, Nigeria publishers (Ltd) Ibadan. L

Ogbodo, S. G., (2009). "Environmental Protection in Nigeria: Two Decades after the Koko Incident," Annual Survey of International \& Comparative Law: Vol. 15: Iss. 1, Article 2. http://digitalcommons.law.ggu.edu/annlsurvey/vol15/iss1/2

Onibokun, A.J. and Faniran A. (1995). “Urban Governance and Urban Poverty in Anglophone West African; CASSAD, Monograph series 4.

Solomon U. (2010). “A Detailed Look at the Three Disciplines, Environmental Ethics, Law and Education to Determine which Plays the Most Critical Role in Environmental Enhancement and Protection. Environment, Development and Sustainability 12(6) P1069-1080.

Taiwo, D.S and Busari, L. (1997)."Preparation of Realistic and Implement able strategy and Action plans for sustainable Development of Cities through the participatory planning Approach of the Environmental Planning and Management process: A case study of the sustainable Ibadan Project: A paper Presented at the $40^{\text {th }}$ annual NITP conference held at NICON, NOGA HILTON HOTEL ABUJA, Nigeria.

Urban Edge (1992). “Coordinating A Global Response to Urban Degradation. 15 (6).

Urban Edge (1991). Local Concerns voiced on urban Environment January \&....February, 15 (6).

UNCHS/UNEP (1997). "Implementing the Urban Environment Agenda". Environmental Planning and management sources book Vol. 11997.

UNCHS/UNEP (1999). "Establishing and supporting working group process" The sustainable city project Vol. 31999. 